Received: Oct 13, 2018; Accepted: Nov 03, 2018; Published: Nov 15, 2018; Paper Id.: IJPSLIRDEC20181

\title{
INTRODUCTION
}

The power of China is best explained by the fact that it has a population of over 1.3 billion people that has great potential and capacity to grow the largest and strongest economy in the world. According to a recent report of the World Bank (2018), China has had an average of unbelievable 10\% GPD growth in last 30 years and that represents the biggest and longest growth in the history of any country. The foundation for this growth was established in 1978 when China started economic reforms and it moved from a centralized economy to a multifunctional market economy. The result of that was unbelievable economic growth that made China the country with second largest economy after the United States. This progress created an extra appetite for China and need to project power in other parts of the world. This is currently being done through the Belt and Road Initiative (BRI).

The start of the ancient Silk Road was from Chang`an (todays Xi'an) todays Mediterranean in the West and in other words, it connected China and Roman Empire (Mark, 2016). This trade brought not just a web of trade, but cultural and scientific interaction between China, India, Persia, Greece and Rome as well. China is now in the $21^{\text {st }}$ century powerful and financially strong with the new BRI platform with the aim of prosperity for all countries that are included. Reality is far different from this idealistic image where the new concept of the Belt and Road has the direct aim of imposing China's interests upon other countries. Many scholars and pundits give 
different analyses of what will be the future of this project and how it will affect other countries and geopolitics.

This paper addresses and aims at explaining three issues:

- What is the BRI and how it evolved?

- Aspects of money and power will be included to find an answer to the dilemma whether the aim of the BRI is to benefit all sides or only one side. In other words, how the BRI is financed and who profits from it. Furthermore, in what ways power is an important factor here and how it affects inter-state relations.

- The platform 16+1 (China and sixteen Eastern European countries) is included to analyse what are the effects of money and power on the states included in the platform.

\section{BELT AND ROAD INITIATIVE}

The paradigm of the BRI project is assumed to build on the historical context of the ancient Silk Road that affected not only trade but the history of the world around us until today. The post-1978 history of China has been marked with extraordinary economic success that provided the incentive for the re-introduction and realization of new and old trade strategy which is a grandiose project based on a vision of historical supremacy. In the $21^{\text {st }}$ century China is economically and financially strong and it is initiating a range of new infrastructure and connectivity projects incorporated in the BRI whose success will depend not only on how is implemented but also on how other countries perceive it and react to it.

Today changes are happening in a world where we have a gradual transition of power from West to East. West is still more powerful in many respects, but the importance of the East is growing and the BRI will add momentum to this process. The world is slowly shifting toward multipolarity and the BRI will contribute to that. Its aim is to maintain free trade and globalization while increasing cultural diversity. The main goal of the BRI is to connect Europe, Asia and Africa and to create positive cooperation at all levels that will help countries improve their economies ("The State Council”, 2015)

In Kazakhstan's Nazarbayev University in 2013, Xi Jinping argued that the Belt and Road is about creating positive cooperation among countries where everybody will respect state sovereignty. He presented a few arguments on how the Silk Road Economic Belt would benefit all parties involved in it. Firstly, it would create better communication between countries by creating a mechanism to develop their economies though dialogue. Secondly, it would build transportation routes that would cut through East Asia, South Asia and West Asia. Third, it would facilitate trade and, fourth, it would provide a framework of how to deal with finance and money. The fifth BRI aim is about promoting different cultures and people-to-people contacts. ("Ministry of Foreign Affairs" [MFA], 2013). In practical terms the BRI is about boosting trade and economic growth in Asia where China will be the one who initiates infrastructure projects and is planning to inject at around $\$ 150$ billion into those projects on the annual basis (Phillips, 2017). This initiative has two branches, a route on land and a maritime route on. The former will try to increase connectivity in the Eurasian landmass, it will focus on the development of "Russia-Mongolia-China, West Asia-Central Asia-China, and Indochina-China economic corridors by taking advantage of international transport routes, relying on core cities along the 'Belt and Road' and using key economic industrial parks as cooperation platforms" (Guoqiang, n.d., para 26). The other part will focus on increasing maritime connectivity between sea ports, as the example of Chinese investments in a range of ports in the Indian Ocean 
and the Mediterranean shows.

This initiative includes 65 countries which make for almost $62 \%$ of the population worldwide. The land area included would beat around $40 \%$ of the world's land area and the overall GDP should be at around 31\% (Hu, Liu \& Yan, 2017). How should we call such a huge project? Can we even call it a project or simply potential for development? "Grand strategy" is a very interesting concept in the field of International Relations but sometimes it is just an interesting word that draws attention but the problem is the following: how can we refer to a grand strategy in such a fast changing environment taking into account that grand strategy remains stable through long stretches of time? Sometimes the grand strategy is not useful because it gives clear guidelines, which means there is no room for adaptation to fast-changing circumstances. Andreea Birzna argues that the BRI strategy as implemented by China, had many opaque aspects and was not developed along the way. Furthermore, understanding the BRI simply as an infrastructure project is a very shallow approach (2018). "Grand strategy" is traditionally considered to be a military strategy aimed at winning a war. If we do not know what the BRI exactly is and what is the goal of it (apart from abstract words like connecting, harmony, infrastructure) how can we even brand it as a grand strategy?

The BRI is a smart power strategy, which means it has elements of culture and the economy where cultural aspects are considered soft power while economic aspects are considered hard power. Furthermore, Brizna argued that the U.S. and Japan in the wake of globalization uses more and more soft power, while China upgraded this approach by combining soft and hard power to become more relevant in the global arena (Brizna, 2016). The current the U.S. Secretary of Defense James Mattis like to say that U.S. has the power of inspiration and the power of intimidation (Transition 2017, 2017). The power of inspiration can be understood as a very vague concept but the power of intimidation is very straightforward and it is expressed through the use of the threat of the use of military force. This means that hard power is used more often to achieve goals than soft power. Every major power tries to combine hard and soft power but one cannot be not sure that the BRI is unambiguously a smart power strategy since we are not completely sure about the nature of this initiative. The tendency to generalize strategies is wrong because of so many different actors involved so, in order to understand the BRI, we have to draw the distinction between the country that initiated it (China) and countries that, because of various reasons, have accepted this initiative.

There are countries with more stable and powerful governments like India and Indonesia and those less powerful and stable like Cambodia and Pakistan. More powerful countries will not allow China to fully dictate terms and vice versa. Developing countries have big interests in the BRI and the funds they can receive to finance projects but there are many risks like the exchange rate, debt, corruption and many other. China argues that there will not be any political pressure but it is well known that market access through BRI strengthens Chinese hegemony and gives China leverage over other economies (Hayes, 2017). Countries in Central and Eastern Europe are not very powerful and rich so they cannot stand up to China. Any investment is beneficial, if not for the countries, then for local politicians who want to show to their people they are able to attract investments to their states.

As previously mentioned, the BRI should not be looked at as a general concept, rather there should be a distinction between China who runs the initiative and the other side's who accept it for various reasons. That is why the next section focuses on the relevance of money and power for the BRI but focuses mainly on China`s side. The section after that discusses the $16+1$ platform where we talk about the reasons behind the decision of those countries to be part of the BRI and what the effects of Chinese investment may be. This ambitious plan starts with the establishment of 
regional dominance, where China wants to have power over its neighbors and affects the affairs in its backyard. The BRI as Eurasian project is appropriate for this strategy (Hong, 2016).

\section{RELEVANCE OF MONEY AND POWER}

President Xi Jinping is the leader who initiated this project in a 2013 visit to Kazakhstan, where he pointed out that the BRI includes three billion people, it has huge potential and it can be the largest market. He further said that the goals of these projects were to enhance monetary circulation, improve road connectivity, promote trade, and increase communication and to create understanding between people. According to this, the BRI should represent a new level of economic trade and a new geopolitical era that will give birth to a new trade philosophy in the $21^{\text {st }}$ century. The initial financial structure is based on the Silk Road Infrastructure Fund, which will receive 40 billion dollars, the Asian Infrastructure Investment Bank (AIIB) with an initial capital of 100 billion dollars and the New Development Bank with 100 billion dollars (Chakhoyan, 2015). There are six strategic economic corridors in the BRI:1) China, Mongolia, Russia Economic Corridor (CMREC), 2) the New Eurasian Land Bridge (NELB), 3) the China Central and West Asia Economic Corridor (CCWAEC), 4) the China-Indochina Peninsula Economic Corridor (CICPEC), 5) the China-Pakistan Economic Corridor (CPEC) and 6) the Bangladesh-China-India-Myanmar Economic Corridor (Hassan, 2016).

If the money comes from state owned enterprises, it is not really clear whether there is direct involvement by a foreign government or not. Even if a company is private, as is often the case in China, most likely it has connections with the government and it probably represents the interests of that government. The problem is that financing projects in today`s world with institutions like the World Bank has become hard for certain states, as such institutions tend to have an attitude against risky investments. Because of that, China founded AIIB, which is believed to be in a position to lend 20 billion dollars per year in its first 5 years. This model is attractive for countries that need money for large projects (Dollar, 2015). Recent developments are that China allowed for Belt and Road bonds that go through the Shanghai and Shenzhen stock exchange and in March 2018 it allowed for foreign and domestic companies to raise 50 billion RMB in bonds (Tan, 2018). The period after the 2008 crisis represents a time when China started becoming a country where outward Foreign Direct Investment (FDI) surpassed inward FDI. Keynesian economics suggest that if countries are incapable of financing their projects, big and rich powers should give them money so they can enter their markets. However, investments in infrastructure projects tend to create huge debt at a national level (Liu \& Dunford, 2016). Out of a sample of 68 countries it is found that 23 countries face the risk of high debt that can affect their economy in the long term and 8 of them, i.e. Pakistan, Djibouti, Maldives, Lao, Mongolia, Montenegro, Tajikistan and Kyrgyzstan risk becoming seriously indebted. Furthermore, another problem is that "China has not signed on to as binding set of rules of the road when it comes to avoiding unsustainable lending and addressing debt problems when they arise" (Shulman, 2018, para 4). If we compare China's BRI with the Marshal Plan it can be argued that there are similarities as both countries China and U.S. behind these big foreign policy initiatives had economies characterized by overcapacity and wanted to find markets for their exports even though the Marshal Plan also included a more military and ideological aspect, while the BRI is more cultural and economic (Shen, 2016). Apart from these differences and the aims of these two initiatives, there is one important aspect in which they differ: the Marshall Plan's main aim was to provide aid to post-World War (western) European countries and did not create debt, while the BRI projects have potential to entrap countries with debt that can have long term negative consequences. 
China is still not capable of challenging the U.S. dominance. The United States is still the leader and the dominant power in many areas compared to other countries. China is emerging and there is fear in the West that China can slowly start building a world order to replace the existing one and the BRI is one way or at least part of this bigger strategy. China thirty years ago kept a low profile, but today it is powerful, rich and is getting ready to challenge the U. S. leadership. It is debatable whether the BRI is a (part of) grand strategy or just an initiative that serves a narrower purpose. Peter Cai argues that the BRI is a very ambitious strategy but it does not have big geopolitical aims; it rather serves a narrow goal. This narrow goal is finding markets for China's manufacturing capacity (2017). We disagree with this view and even though one may not call the BRI a grand strategy, it would not be considered as a narrow strategy that tries to satisfy such small part of Chinese needs. Every strategy evolves along the way and it is modified according to new needs and a changing environment. The U.S. built the Breton Woods institutional system, which served their interests well and helped them project influence. China`s newly established institutions like AIIB, NDB and Silk Road have the same purpose and that is to increase Chinese power (Overholt, 2015). The BRI can be seen as a power play in Asia, where the U.S. has been enhancing its military alliances with other countries in the Asia Pacific or encourage other great powers in the Indo-Pacific, like Japan and India to deepen their cooperation. This is a warning to China that it has to act (Aoyama, 2016). The BRI will have implication to use economic and political leverage to influence other countries, to solve disputes and to create different routes that are beneficial for China. Furthermore, it has the potential to project capabilities in the form of sending military abroad (Swaine, 2015). China's BRI is not a tightly knit grand strategy and definitely it is not a narrow strategy that tries to satisfy a particular industry in China like manufacturing overcapacity, but it is a strategy that has long-term adaptable goals to serve Chinese interests and to make China more powerful and a global power. And, it is put properly by Peter Ferdinand:"In the longer term, all of this will help China to become more of a global as opposed to an Asian power. And from the perspective of Chinese go, it is also the sort of strategy that a player might adopt in a long game to surround or neutralize an opponent's more exposed or isolated pieces before gathering forces for an assault on the main stronghold" (2016, p. 954).

\section{The 16+1 PLATFORM}

The new route or part of the whole BRI initiative, an essential part of the project is in Central and Eastern Europe and includes sixteen countries. These countries are Estonia, Latvia, Lithuania, Poland, Czech Republic, Slovakia, Hungary, Romania, Bulgaria, Slovenia, Croatia, Albania, Montenegro, Serbia, Bosnia and Herzegovina and Macedonia. These countries and this part of Europe is disproportional in a sense of different economic development, relatively unstable politics, recent war history, different social problems and different level of integration in different institutions. These different issues make this part of the world very unwanted and to some extent very difficult for any successful economic integration. The idea of this platform was pursued at first forum in 2011 in Budapest and this represented in the First Economic Forum ("Premier Li vows to bring China-CEEC cooperation”, 2017).

The first summit was in 2012 in Warsaw, where first projects for cooperation were initiated. Moreover, the first investment fund was launched between China and 16 Central and East European countries. China would provide two million Yuan every year starting 2013. The second one was in 2013 in Bucharest, the third one in Belgrade in 2014, the fourth one in Suzhou in 2015 and the next in Riga in 2016. The aim of the 16+1 platform is to create further cooperation mechanisms between these countries that will potentially include trade, economy, finance, culture, education and many other ("Introduction of research fund", 2013). 
Kong Tianping argues that China has adopted a regional approach toward the CEE countries that emerged in the last couple of years. This approach is based on mutual interest, equal footing, not so regulated institutionalization with political tendency and economic interests (2015). When China's Premier spoke in 2012 at the meeting in Warsaw, Poland, he talked about different outlines that should guide cooperation between China and the $16 \mathrm{CEE}$ countries. He said that both sides should value each other and create understanding and trust. Furthermore, economic cooperation can be enhanced through different mechanism and with closer cultural ties. Last but not least, he stressed the importance that relations between China and the 16 CEE countries can enhance the overall cooperation between China and Europe ("Wen outlines proposals", 2012).

The CEE states reacted in different ways. One type of reaction was "high level bilateral and multilateral meeting in which support towards the strategy is expressed. Second is research and strategic planning to develop OBOR and the third is supporting documents outlining specific policies, such as memoranda of understanding" (as cited in Stanzel, 2016, para 10). On the one hand, China will probably continue to invest in the CEE countries in different infrastructure projects because of China this represents the entrance to the market of the EU. On the other hand, there is a huge burden on China because countries in East and Central Europe have high expectations from China`s investments. On top of that there is serious skepticism from the EU about this initiative and what is the end goal for China in this part of the world (Brown, 2017). This again leads us to the question of money and power and even though both sides have some sort of interest at least in theory, the puzzle is whether both sides can profit, if one side is clearly more powerful than the other.

Countries in East and Central Europe are less developed so there is concern in the EU that they might become dependent of Chinese investment and in that way China can affect their policies and local politics. Now China likes the fact that those countries are close to the EU because in that way it can have connections and useful partners that can lobby in the EU. Nevertheless, this does not mean that China would not start influencing CEE countries in ways that are against EU interests.

Chinese investments in CEEC countries can contribute to building infrastructure, but they can create huge debt and imbalance in trade (Giusti, 2013). The best example of this is a case in Montenegro where the government signed an agreement with the Chinese Communication Construction Company (CRBC) worth 809 million euro's to construct a 45-kilometer long highway. The problem with the deal is that it is not transparent and it will have negative effects on the levels of debt. It is believed that the debt will increase by $23 \%$ and as a result the total amount of debt will reach $83 \%$ of the country's GDP. Since this highway connects the country to Serbia, all this is being justified by the Montenegrin government that it will improve connectivity between Montenegro and Serbia and increase trade (Tomovic, 2018). The Chinese debt model can be of importance for the CEEC countries, which sometimes have a hard time getting EU funds and loans from international financial institutions. For CEEC countries, acceptance of this can result into breaches of their legal systems and can have with political costs. The potential positive scenario can be to create some interconnected model between China, the CEEC countries and the EU, if China can learn to adapt to the EU law and transparency, but it can go the other way with the zero-sum mentality where China only pushes their own interest and the CEE countries look for quick investment that would potentially lead to debt and incur the political costs (Jakobowski \& Kaczmarski, 2017).

China is trying to project a positive imagine through the creation of 21 Confucius institutes in CEE countries (Simurina, 2014). With such actions, it wants to project the imagine of a benevolent hegemon that does not wish harm to any of the CEE countries and that it only wants a result that would benefit all parties involved. The EU is still most the 
important players in CEE countries. China is quietly approaching this region and is being more cautious than other powers because it is a rising power and does not want to scare anybody away. Furthermore, China wants stable and peaceful cooperation with the CEEC countries because this would give China power from within the EU. China still cannot lead the CEEC countries and it does not have potential to divide those countries, but through relation, cooperation and lending money it can gradually build up power so it can divide them if it serves its purposes (Turcsanyi, 2014).

\section{CONCLUSIONS}

After enormous economic success, the time arrived from China to launch there that will satisfy their needs, increase prestige and deal with the challenges of $21^{\text {st }}$ century geopolitics. The ancient silk road was about prestige and power so this new version is all about prestige, domination and bringing back old glory. Nevertheless, this updated initiative, according to China is for everybody to benefit and to connect a world that would be based on mutual understanding and mutual gain. Grand strategy usually has the negative connotation of a plan by a certain country to dominate another country and because of that the BRI is not labeled as such. It is considered to focus on infrastructure projects that would benefit everybody and it would be upgraded along the way. It is a smart power strategy because it has elements of both cultures, which is soft power, and economy, which is hard power.

The relevance of money and power is different in the eyes of China and those who receive funds. China developed AIIB that can lend money to potential infrastructure projects in the Belt and Road countries. This initiative still cannot completely challenge the western order, but it can have gradual increase of power and relevance. A good example of this is provided by the $16+1$ platform where countries are not strong enough to challenge China and they have to accept funds for infrastructure projects to improve their economies. It is presented as a project where everybody will gain, but in the case of Montenegro we can see that it can have long lasting consequences on the country's debt. This is an adaptable grand strategy to project power in different parts of the world and to create political leverage that can be used in the future to achieve political goals in the rapidly changing geopolitical environment of the $21^{\text {st }}$ century.

\section{REFERENCES}

1. Aoyama, R. (2016). "One belt, one road": China's new global strategy. Journal of Contemporary East Asia Studies, 5(2), 322. URL: http://dx.doi.org/10.1080/24761028.2016.11869094

2. Brizna, A. (2018, March 20). Redefining the Belt and Road initiative. The Diplomat. Retrieved from: https://thediplomat.com/2018/03/redefining-the-belt-and-road-initiative/

3. Brizna, A. (2016, September 30). China: from panda diplomacy to new Silk Road smart power. The Romanian Institute for the Study of the Asia Pacific Retrieved from: http://risap.ro/en/china-panda-diplomacy-new-silk-road-smart-power/

4. Brown, K. (2017, May 3). China's geopolitical aims: the curious case of the 16 plus 1. The Diplomat. Retrieved from: https://thediplomat.com/2017/05/chinas-geopolitical-aims-the-curious-case-of-the-16-plus-1/

5. Chakhoyan, A. (2015, November 10). 5 things to know about the new Silk Road. Word Economic Forum. Retrieved from: https://www.weforum.org/agenda/2015/11/5-things-to-know-about-the-new-silk-road/

6. Dollar, D. (2015, July 15). China's rise as a regional and global power: the AIIB and the 'one belt one road'. Brooking Institution. Retrieved from: https://www.brookings.edu/research/chinas-rise-as-a-regional-and-global-power-the-aiib-and-theone-belt-one-road/ 
7. Ferdinand, P. (2016, June 20). Westward ho - the China dream and 'one belt, one road': Chinese foreign policy under Xi Jinping. International Affaris, 92(4), 941-957. URL: https://doi/org/10.1111/1468-2346.12660

8. Hassan, H. (2016, August 14). China 6 magical economic corridor. Foreign Policy News. Retrieved from: http://foreignpolicynews.org/2016/08/14/china-6-magical-economic-corridor/

9. Giusti, S. (2013). China: an emerging stakeholder in Eastern Europe (No. 153). Milan, Italy: Instituto Per Gli Studi Di Politica Internazionale. Retrieved from: https://www.ispionline.it/it/documents/Analysis_153_2013.pdf

10. Hayes, N. (2017). The impact of China`s One Belt One Road initiative on developing countries [Blog post]. Retrieved from: http://blogs.lse.ac.uk/internationaldevelopment/2017/01/30/the-impact-of-chinas-one-belt-one-road-initiative-on-developingcountries/

11. Hong, Y. (2016). Motivation behind China`s One Belt, One Road initiatives and establishment of the Asian Infrastructure Investment Bank. Journal of Contemporary China, 26(105), 1-16,

DOI: $10.1080 / 106770564.2016 .12455894$

12. Hu, B., Liu, Q., \& Yan, J. (2017, October 25,). Adding '5+1' to China 's Belt and Road initiative. East Asian Forum. Retrieved from: http://www.eastasiaforum.org/2017/10/25/adding-5-1-to-chinas-belt-and-road-initiative/

13. Introduction of research fund on China - Central and Eastern Europe relation. (2013, November 28). Cooperation between China and Central and Eastern European countries. Retrieved from:

http://www.china-ceec.org/eng/yjjj__l/jj/t1410655.htm

14. Jakobowski, J., \& Kaczmarski, M. (2017, September 15). Beijing `s mistaken offer: the '16+1' and China's policy towards the European Union. Centre for Eastern Studies. Retrieved from:

https://www.osw.waw.pl/en/publikacje/osw-commentary/2017-09-15/beijings-mistaken-offer-161-and-chinas-policy-towardseuropean

15. Li: the new billions of dollars for CEE countries. (2017, November 27). Daily Journal Politics. Retrieved from: http://www.politika.rs/sr/clanak/393308/Danas-samit-Kine-i-16-zemalja-CEE-u-Budimpesti

16. Liu, W., \& Dunford M. (2016). Inclusive globalization: Unpacking China`s Belt and Road initiative. Area Development Policy, OO(00), 1-18, DOI: 10.1080/23792949.2016.1232598

17. Mark, J. J. (2018, May 1). Silk road. Ancient History of Encyclopedia. Retrieved from: https://www.ancient.eu/Silk_Road/

18. Ministry of Foreign Affairs of the People's Republic of China (2013). President Xi Jinping delivers important speech and proposes to build a Silk Road Economic Belt with Central Asian countries. Retrieved from: http://www.fmprc.gov.cn/mfa_eng/topics_665678/xjpfwzysiesgjtfhshzzfh_665686/t1076334.shtml

19. Overholt, H. W. (2015, September 26). One belt, one road, one pivot. Global Asia. Global Asia. Retrieved from: https://www.globalasia.org/bbs/board.php?bo_table=articles\&wr_id=8764

20. Peter, C. (2017). Understanding China`s Belt and Road initiative. Sydney, Australia: Lowy Institute. Retrieved from: https://www.lowyinstitute.org/publications/understanding-belt-and-road-initiative

21. Phillips, T. (2017, May 12). The \$900bn question: What is the Belt and Road initiative? The Guardian. Retrieved from: https://www.theguardian.com/world/2017/may/12/the-900bn-question-what-is-the-belt-and-road-initiative 
22. Premier LI vows to bring China-CEEC cooperation, China - Hungary ties to new level. (2017, November, 26). Xinhua Net. Retrieved from: http://www.xinhuanet.com/english/2017-11/26/c_136780275.htm

23. Stanzel, A. (2016). China's investment in influence: the future of 16+1 cooperation. Retrieved from: https://www.ecfr.eu/publications/summary/chinas_investment_in_influence_the_future_of_161_cooperation7204\#_ftn5

24. Shen, S. (2016, February 6). How Chin's Belt and Road compares to the Marshall plan. The Diplomat. Retrieved from: https://thediplomat.com/2016/02/how-chinas-belt-and-road-compares-to-the-marshall-plan/

25. Shulman, H. (2018, March 4). China`s Belt and Road initiative heightens debt in eight countries, points to need for better lending practices. Center for Global Development. Retrieved from:

26. https://www.cgdev.org/article/chinas-belt-and-road-initiative-heightens-debt-risks-eight-countries-points-need-better

27. Simurina, J. (2014). China`s approach to the CEE-16 (2010/256-524). London, United Kingdom: Europe China Research and Advice Network. Retrieved from:

http://eeas.europa.eu/archives/docs/china/docs/division_ecran/ecran_is107_paper_85_chinas_approach_to_the_cee16_jurica_simurina_en.pdf

28. Swaine, D. M. (2015). Chinese views and commentary on the "one belt, one road" initiative. California, US: Hoover Institution. Retrieved from: https://www.hoover.org/sites/default/files/research/docs/clm47ms.pdf

29. Tianping, K. (2015). 16+1 cooperation framework: genesis, characteristics and prospect. Retrieved from: http://16plus1thinktank.com/1/20151203/868.html

30. Tan, C. (2018, March 7). China to step up financing for Belt and Road projects. Nikkei Asian Review. Retrieved from: https://asia.nikkei.com/Spotlight/China-people-s-congress-2018/China-to-step-up-financing-for-Belt-and-Road-projects

31. The State Council: The people's Republic of China (2015, March 30). Full text: action plan on the Belt and Road initiative. Retrieved from: http://english.gov.cn/archive/publications/2015/03/30/content_281475080249035.htm

32. The Work Bank. (2018, September 26). The World Bank in China. Retrieved from: https://www.worldbank.org/en/country/china/overview

33. Shakya, G. Relevance of pali tipinika literature to modern world.

34. Tomovic, D. (2018, April 2). Highway deal with Chinese arouses suspicions in Montenegro. Balkan Insight. Retrieved from: http://www.balkaninsight.com/en/article/montenegro-mulls-new-highway-deal-with-chinese-companies-03-30-2018

35. Transition 2017. (2017, January 12). Mattis: US has power of intimidation and inspiration, latter needs to "be employed just as strongly" [Video file]. Retrieved from: https://www.youtube.com/watch? $v=B K i i z q Z E I 7 w$

36. Turcsanyi, R. (2014). Central and Eastern Europe`s courtship with China: Trojan horse within the EU? Brussels, Belgium: European Institute for Asian Studies. Retrieved from: http://www.eias.org/wp-content/uploads/2016/02/EU-Asia-at-a-glanceRichard-Turcsanyi-China-CEE.pdf

37. Guoqiang, C. (n.d.). The Belt and Road - a mission to benefit two-thirds of the world. Center for International Relations and Sustainable Development. Retrieved from: https://www.cirsd.org/en/horizons/horizons-summer-2015--issue-no4/the-belt-androad---a-mission-to-benefit-two-thirds-of-the-world-

38. Wen outlines proposals on building closer China-Central, Easter Europe ties. (2012). Retrieved from: http://www.chinaceec.org/eng/ldrhw_1/2012hs/hdtj/t1410550.htm 
